\title{
ПОЛІТИКА ФРАНЦІЇ У СФЕРІ ВРЕГУЛЮВАННЯ ПРОБЛЕМИ НЕЛЕГАЛЬНОЇ МІГРАЦІЇ
}

\begin{abstract}
Анотація: Стаття присвячена висвітленню політики Франиії у сфері врегулювання проблеми нелегальної міграції, яка відіграла важливу роль у політичній трансформації країни та держав EC в цілому. Світова фінансово-економічна криза 2009 р., конфліктогенність у країнах третього світу внесла серйозні «корективи» у процес нелегальної міграції до європейських країн, яка упродовж наступних років переросла у важко контрольований процес, який наразі є серйозним дестабілізуючим фактором безпеки иілого регіону. Упродовж останніх п'ятнадияти років міграційна політика ЄC суттєво змінилася та набула нового змісту. Однак, як показує приклад боротьби Франиії з нелегальною мігращією, зробити це одному а́ктору надзвичайно важко, оскільки дана проблема має вже не національний, а міжнародний характер.

Ключові слова: нелегальна міграція, мігращійна політика, Франщіл, $Є C$
\end{abstract}

На сьогоднішній день одним з негативних явищ, яке впливає на розвиток і безпеку країн Європейського Союзу є нелегальна міграція, яка з національного рівня переросла на міжнародний. Перед країнами ЄC постало серйозне завдання виробити єдину тактику вирішення цієї загрози. Як відомо, найбільше від нелегальної міграції потерпають саме економічно розвинені та політично стабільні країни, серед таких одна із основоположниць ЄC - Франція.

Мета статmі: розглянути питання нелегальної міграції у Франції та дію уряду у протистоянні цій небезпеці.

За останні 20 років з'явилася низка праць як серед вітчизняних, так і закордонних дослідників щодо висвітлення нелегальної міграційної політики та іï впливу в країнах Європейського Союзу. Серед таких на особливу увагу заслуговують роботи українських науковців О. Малиновської ${ }^{1}$, О. Гільченко ${ }^{2}$, Ю. Драча ${ }^{3}$ та I. Сльоти ${ }^{4}$, які наголошують на

\footnotetext{
•Вовчук Людмила Анатоліївна - кандидат історичних наук, доцент кафедри міжнародних відносин та зовнішньої політики Чорноморського національного університету імені Петра Могили (Миколаїв, Україна); ORCID: https://orcid.org/0000-0002-8324-5235; e-mail: luda_vovchuk@ukr.net

Авдюшкіна Інна Сергіївна - магістр кафедри міжнародних відносин та зовнішньої політики Чорноморського національного університету імені Петра Могили (Миколаїв, Україна); ORCID: https://orcid.org/0000-0002-0623-6343; e-mail: avdyushkinainna90@gmail.com

${ }^{1}$ Малиновська О. Міграційна політика: глобальний контекст та українські реалії. Київ: НІСД, 2018. 472 с.; Малиновська О.А. Формування спільної міграційної політики Європейського Союзу // Стратегічна панорама. 2006. № 2. URL: http://www.niisp.org/vydanna/panorama/issue.php?s=gupr0\&issue=2006_2

${ }^{2}$ Гільченко О.Л. Сучасна міграційна політика Франції // Вісник Маріупольського державного університету. Серія: Історія. Політологія. 2016. Вип. 16. С. 191-199.

${ }^{3}$ Драч Ю.С. Зовнішньополітичні аспекти імміграційної політики Франції // Гілея: науковий вісник. 2011. Вип. 48. № 6. С. 876-881.
} 
тому, що щороку кількість нелегальних мігрантів активно зростає і цей процес серйозно позначається на внутрішньополітичному та внутрішньоекономічному розвиткові європейських країн. У свою чергу, збільшення міграційних потоків призводить до активізації тероризму, збільшення рівня злочинності, зіткнень на релігійній основі, росту безробіття та величезних державних витрат на допомогу мігрантам.

Значний інтерес до даної тематики спостерігається і серед представників російської історіографії. Варто виокремити праці Л. Абазалова ${ }^{5}$, Ю. Литвинова та О. Потьомкіна ${ }^{6}$, А. Ромашова ${ }^{7}$ та Я. Стрєльцова ${ }^{8}$, які, роблячи акцент на правових засадах імміграційної політики в європейських країнах, висвітлюють наскільки ефективною є міграційна політика ЄC на сучасному етапі. Окрім того, автори погоджуються у тому, що головною перешкодою на шляху інтеграції новоприбулих мігрантів (які в основному є мусульманами) $є$ їхня релігія та традиції, які не відповідають світському характеру держав Заходу.

Досить грунтовними у даному випадку $є$ напрацювання європейських та американських науковців. Серед таких на особливу увагу заслуговують роботи Р. Гропаса та С. Каррера ${ }^{10}$, які висловлюють пропозиції щодо необхідності країнам ЄC керувати міжнародними переміщеннями населення з урахуванням реальних можливостей прийому мігрантів 3 точки зору ринку праці, забезпечення житлом, доступу до охорони здоров'я, освіти та соціальних послуг, а також захисту від можливої експлуатації.

Упродовж останніх п'ятнадцяти років міграційна політика ЄС суттєво змінилася та набула нового змісту. Колишні неформалізовані міжурядові контакти еволюціонували у повноцінний законодавчий блок співтовариства, вагому частину «acquis communautaire». Це відбулося внаслідок об’єкивної потреби у виробленні спільних підходів до регулювання міграційними процесами, як внаслідок їх інтенсифікації всередині і поза межами співтовариства, так і в контексті поглиблення європейської інтеграції як такої.

Починаючи 31997 р., з моменту активізації зростання нелегальних міграційних потоків до європейських країн, було підписано добре відому Амстердамську угоду ${ }^{11}$, де окремою частиною прописувалися правила щодо пересування та надання притулку прибулим мігрантам. У жовтні 1999 р. на саміті у Тампере (Фінляндія) глави держав ЄС

\footnotetext{
${ }^{4}$ Cльота I. Сучасна міграційна політика Франції та Великої Британії // UA Foreign Affairs. 2014. 12 листопада. URL: $\quad$ http://uaforeignaffairs.com/ua/ekspertna-dumka/view/article/suchasna-migraciina-politika-franciji-tavelikoji-britan/

${ }^{5}$ Абзалова Л.Ф. Правовые аспекты иммиграционной политики в странах Европейского Союза. Четвертые Валентеевские чтения: Сборник докладов (Книга 2). Москва: МАКС-Пресс, 2005. С. 121-127.

${ }^{6}$ Потемкина О. Европейская повестка дня по миграции - новый поворот в иммиграционной политике ЕС // Современная Европа. 2015. № 4. С. 28-40.

${ }^{7}$ Ромашова А.Г. Миграционная политика Франции как следствие социальных противоречий // Алтайская школа политических исследований. 2013. 29 июня. URL: http://ashpi.asu.ru/ic/?p=2292

${ }^{8}$ Стрельцова Я. Современная миграционная политика Франции // Мировая экономика и международные отношения. 2020. Т. 64. № 8. С. 120-127.

${ }^{9}$ Gropas R. European Immigration: a sourcebook. Ashgate Publishing, 2014. 448 p.

${ }^{10}$ Carrera $S$. The French Presidency's European Pact on Immigration and Asylum: Intergovernmentalism vs. Europeanisation? Security vs. Rights? // CEPS Policy Brief (Brussels). 2008. № 170. P. 5-25.

${ }^{11}$ Treaty of Amsterdam amending the Treaty on European Union, the Treaties establishing the European Communities and certain related acts. URL: http://eur-lex.europa.eu/legalcontent/EN/TXT/?uri=CELEX\%3A11997D\%2FAFI
} 
домовилися про реалізацію Амстердамської угоди. Було схвалено спеціальну програму щодо створення спільної системи регулювання міграцій в ${\Theta C^{12}}^{2}$

У рамках цієї програми вже в 2000 р. Європейська Комісія (ЄК) видає перший розгорнутий документ щодо спільної імміграційної політики $\mathrm{EC}^{13}$, а у грудні 2005 р. після тривалих багатосторонніх консультацій $Є К$ було затверджено Політичний план щодо легальної імміграції ${ }^{14}$, прийняття якого ознаменувало підтвердження зміни імміграційної політики ЄC від раніше цілком обмежувальної до більш прагматичної та відкритої, що пояснювалася демографічним спадом, потребою у кваліфікованих працівниках для розбудови «економіки знань», а також культурного збагачення та додаткових джерел підприємництва й інновацій.

у 2008 р. ЄК, підбивши підсумки першого етапу формування міграційної політики $\epsilon^{15}$, сформулювала принципи імміграційної політики $Є C$, які й стали основними напрямами діяльності у міграційній сфері. Серед таких принципів були: створення ясної та прозорої системи правил і процедур з метою забезпечення легальної імміграції16, а також економічна імміграція мала відповідати потребам ринку праці $Є C$, причому не лише за кількістю, а й за якістю, тобто за професійно-кваліфікаційним складом, сприяти економічному зростанню ${ }^{17}$.

Окрім того, у жовтні 2008 р. на саміті в Брюсселі держави-члени ЄС підписують Європейський пакт, який не будучи юридично обов'язковим, закріплює низку політичних домовленостей між країнами ЄC щодо регулювання міграційних процесів ${ }^{18}$. Зокрема, у Пакті наголошувалося, що міграція може зробити вагомий внесок в економічний розвиток Європейського Союзу, а також забезпечити ресурсами самих мігрантів і країни їхнього походження, сприяти таким чином їх розвиткові ${ }^{19}$.

Наступною була ухвалена 6 жовтня 2009 р. Стокгольмська програма ${ }^{20}$, яка закріпила вже досягнуті результати європейських держав у питанні міграційної політики. 1 грудня 2009 р. набрала чинності Лісабонська угода, яка внесла суттєві зміни у функціонування ЄС (Ст. 68) $)^{21}$.

Пакт про імміграцію та притулок було схвалено у момент розгортання світової

\footnotetext{
${ }^{12}$ Малиновська О.А. Формування спільної міграційної політики...

${ }^{13}$ European Agenda on Migration. URL: https://ec.europa.eu/home-affairs/what-we-do/policies/european-agendamigration_en

${ }^{14}$ Вишневська О.А. Сучасна міжнародна трудова міграція та державна міграційна політика // Статистика України. 2008. № 2. С. 87.

${ }^{15}$ Policy plan on legal migration. URL: http://eur-lex.europa.eu/legal-content/GA/TXT/?uri=uriserv:114507

${ }^{16}$ Толстов С.В. Динаміка та напрями інститущіональних реформ у Європейському Союзі // Актуальні проблеми міжнародних відносин. 2014. Вип. 120, ч. 1. С. 27-36.

${ }^{17}$ Common principles for an EU immigration policy // Statewatch. 2016. URL: http://www.statewatch.org/news/2008/jun/eu-com-immigration-citizen-note.pdf

${ }^{18}$ Малиновська О. Міграційна політика: глобальний контекст та українські реалії... С. 137.

${ }^{19}$ European Pact on Immigration and Asylum. URL: http://eur-lex.europa.eu/legalcontent/EN/TXT/?uri=URISERV\%3Aj10038

${ }^{20}$ The Stockholm Programme - an open and secure Europe serving and protecting the citizen. URL: https://ec.europa.eu/anti-trafficking/sites/antitrafficking/files/the_stockholm_programme_-

_an_open_and_secure_europe_en_1.pdf

${ }^{21}$ Treaty of Lisbon amending the Treaty on European Union and the Treaty establishing the European Community. URL: http://eur-lex.europa.eu/legal-content/en/TXT/?uri=CELEX\%3A12007L\%2FTXT
} 
фінансово-економічної кризи, що не могло не вплинути на його реалізацію. У результаті, криза та революційні події в країнах південного та східного Середземномор'я, звідки до Європи був спрямований численний міграційний потік, спонукали Єврокомісію у 2011 р. виступити 3 новим закликом розгляду проблеми міграції. Окрім переліку термінових заходів, ЄК наголошувала на необхідності завершити формування європейської системи притулку, укріплення кордонів, кращого регулювання легальної імміграції до ЄС осіб, що мають необхідний економіці країн ЄС фах, поширення передового досвіду щодо інтеграції мігрантів ${ }^{22}$.

Не дивлячись на низку прийнятих документів щодо міграційної політики, питання нелегальної міграції у країнах Європейського Союзу залишалося на порядку денному. Яскравим прикладом «боротьби» 3 цим дестабілізуючим фактором безпеки регіону можуть послугувати дії однієї з економічно розвинених і, в результаті, привабливих європейських країн - Франції.

Упродовж XX - початку XXI ст. Франція розглядалася іммігрантами як одна 3 найкомфортніших країн. Розквіт промисловості, успіхи у фінансовому секторі, високий статус на міжнародній політичній арені, широкий спектр можливостей і райдужні перспективи для різних сфер суспільного життя (у т.ч. культури та мистецтв), а головне реальна можливість вільно, без обмежень і прив'язок до усталених норм проявляти сутність i нове бачення, стали одним із визначальних факторів для розвитку французького суспільства в цілому ${ }^{23}$.

Аналіз французької міграційної політики періоду 2000-2006 рр. показав, що уряд неодноразово намагався вирішити проблему іммігрантів, у тому числі через зміни законодавства та шляхом інтеграції останніх до суспільства. Міграційна політика французького уряду здійснюється за трьома напрямками: а) управління міграційними потоками; б) боротьба проти нелегальної імміграції; в) інтеграція іммігрантів, що живуть у країні ${ }^{24}$.

Одним із найголовніших лобістів упровадження оновленого пакету міграційної політики по праву вважається Ніколя Саркозі, який був обраний президентом країни у 2007 р. За час його політичної кар'єри було прийнято низку досить жорстких та обмежуючих законів і поправок до нормативних актів, головною метою яких стало покращення загального суспільного клімату. На відміну від свого попередника Ж. Ширака, Н. Саркозі неодноразово робив спробу вирішити питання з нелегальною імміграцією, розробивши низку нових норм, які сприяли значному поверненню іноземців на батьківщину ${ }^{25}$. Однією 3 них стала введена система квот, суть якої полягала у тому, що

\footnotetext{
${ }^{22}$ Carrera S. The French Presidency's European Pact on Immigration and Asylum: Intergovernmentalism vs. Europeanisation? Security vs Rights? P. 5.

${ }_{23}^{23}$ Оврамець М.А. Європейський мультикультуралізм у дискурсі політології міжнародних відносин // Вісник Маріупольського державного університету. Серія: Політологія. Історія. 3б. наук. праць. Маріуполь, 2013. Вип. 7-8. С. 111-113.

${ }^{24}$ Павлова Е.Б. Понятие мультикультурализма в современном политическом дискурсе // Политическая наука и политические процессы в Российской Федерации и в новых независимых государствах. Екатеринбург: Издво УрОРАН, 2005. С. 24-25.

${ }^{25}$ Меркель заявила о провале мультикультурализма // BBC. Русская служба. 2010. 17 октября. URL: http://www.bbc.com/russian/international/2010/10/101016_merkel_multiculturalism_failed.shtml
} 
отримати пільгове посвідчення на проживання у Франції могли вчені, представники мистецтва, артисти та спортсмени, для усіх інших встановлювалися досить жорсткі умови ${ }^{26}$.

Окрім того, був прийнятий базовий документ у сфері узгодження міграційної політики країн $Є C$ - Європейський пакт про імміграцію та надання притулку ${ }^{27}$, який мав стати основою європейської політики щодо імміграції та надання притулку на основі взаємної відповідальності і солідарності між державами-членами.

Для регулювання міграційних процесів французький уряд створив багатоступеневу систему державних установ та органів: 1) Міністерство 3 соціальних справ, праці і солідарності (до складу якого входять такі організації та служби як ADRI, FASILD, OFPRA, SSAE, ASSFAM, DPM); 2) Міністерство внутрішніх справ, яке складається з Управління у сфері громадянських свобод i Центрального управління прикордонної поліції, що безпосередньо контролює міграційні потоки і бореться 3 нелегальною міграцією; 3) Міністерство закордонних справ, що відстоює інтереси французьких громадян за кордоном та іноземних громадян у Франції; 4) Міністерство юстиції, що включає в себе Управління 3 цивільних справ, яке займається вирішенням питань щодо надання громадянства ${ }^{28}$.

Однак, політика мультикультуралізму, якої дотримувалися Франція, Англія та Німеччина у питанні міграції, не виправдала себе. у жовтні 2010 р. канщлер ФРН А. Меркель визнала недолугість запровадженої урядом стратегії міграційної політики, зазначивши, що ті, хто бажає стати частиною німецького суспільства, зобов'язані дотримуватися законів приймаючої країни, поважати усталені традиції та розмовляти державною мовою ${ }^{29}$. у лютому 2011 р. такої ж думки був і англійський уряд. Прем'єрміністр країни Д. Кемерон у своєму виступі на міжнародній конференції 3 питань проблем безпеки наголосив на необхідності дати можливість іммігрантам інтегруватися у приймаюче суспільство глибше . $^{30}$

Останнім, хто наважився визнати крах застосування «політики вінегрету» серед європейських урядовців, став Н. Саркозі, який у своєму інтервю від 11 лютого 2011 р. зазначив, що приймаючи мігрантів, потрібно було більше перейматися не ідентичністю особи, а країною їх походження.

Новообраний у 2012 р. президент Франції Ф. Олланд, зосередившись на вирішенні економічних і зовнішньополітичних питань країни (вирішення воєнного конфлікту в Малі за участю французьких збройних сил, відведення військ з Афганістану), тимчасово абстрагувався від вирішення проблеми міграції.

Станом на 2013 р. ситуація в країні щодо міграції значно загострилася. У префектурах Франції накопичилося понад 66 тис. досьє шукачів притулку. Враховуючи той факт, що у середньому на розгляд кожної справи йшло 2 роки, це призвело до виникнення стихійних наметових містечок і захопленню нежитлових приміщень. У результаті країною

\footnotetext{
${ }^{26}$ Ibidem.

${ }^{27}$ UNHCR - France // The UN Refugee Agency [official web-site]. 2017. URL: http://www.unhcr.org/france.html

${ }^{28}$ European Pact on Immigration and Asylum. URL: http://eur-lex.europa.eu/legalcontent/EN/TXT/?uri=URISERV\%3Ajl0038

${ }^{29}$ Європейський Союз: політика, економіка, право. Навч. посібник / За ред. Н.В. Антонюк, М.М. Микієвича. Львів: Львівський нац. ун-т ім. І. Франка, 2005. С. 200-202.

${ }^{30}$ Драч Ю.С. Зовнішньополітичні аспекти імміграційної політики Франції...
} 
прокотилася хвиля антиіммігрантських настроїв у суспільстві. Тому, вже 23 липня 2014 р. Радою Міністрів було прийнято одразу два законопроекти, що дозволяли регулювати імміграцію ${ }^{31}$.

Заключним етапом реформування французької міграційної політики стало прийняття 8 березня 2016 р. «Закону про права іноземців», який містив положення стосовно прийому та інтеграції іммігрантів, нового порядку надання посвідки на проживання, а також положення щодо нелегальних мігрантів у країні ${ }^{32}$. Головним завданням нового закону було створення надійного механізму інтеграції, що зменшило б градус напруженості та ненависті до біженців і вимушених переселенців у суспільстві, який різко підскочив після терактів у листопаді 2015 p. $^{33}$

Однак загострення міграційної кризи в Європі та збільшення неконтрольованих потоків біженців виявили неспроможність як існуючих інститутів $Є C$, так і національних урядів вчасно та компетентно вирішувати ці питання.

Президентські вибори у Франції в 2017 р. і перемога на них Е. Макрона проходили на тлі міграційної кризи 2015 р. в Європі ${ }^{34}$. Імміграційна політика новообраного президента стосувалася підтримки дій держав ЄC з охорони зовнішніх кордонів. Цей напрямок передбачав: зміцнення поліцейського корпусу та збільшення чисельності прикордонної поліції (до 5 тис. осіб) у рамках побудови єдиної загальноєвропейської системи прикордонного контролю; створення контрольно-пропускних пунктів у державах витоку мігрантів з метою обмеження числа біженців до прибуття в країни $Є C$; посилення боротьби 3 нелегальною імміграцією в ЄС та її організаторами ${ }^{35}$.

На початку березня 2020 р. Франція долучилася до стримування потоків біженців 3 Туреччини до Греції та Болгарії, кількість яких досягла майже 11 тис. Після загострення ситуації в Сирії, 28 лютого 2020 р. президент Туреччина Ердоган заявив, що не може впоратися з кількістю людей (17 тис.), які рятуючись від війни, хочуть потрапити у сусідні держави-члени $\mathrm{EC}^{36}$.

А в липні 2021 р. Франція та Англія підписали угоду щодо посилення контролю на кордонах, а саме патрулів на узбережжі Ла-Маншу, а також про значне інвестування у технології, які допоможуть більш ефективніше здійснювати контроль. Франція збирається подвоїти чисельність поліції на північному узбережжі, між містами Булонь і Дюнкерк і навколо порту Дьєпп, а також посилити повітряні патрулі. Лондон зі свого боку допоможе 3 фінансуванням притулків для мігрантів у Франції, зокрема інвестує протягом року

\footnotetext{
${ }^{31}$ Телкова Т.О. Нелегальная миграция во Франции и методы борьбы с ней // Журнал «Панорама». Воронеж, 2020. C. 52-57.

${ }^{32}$ Франция примет новый закон о статусе иностранцев // «Голос со всего мира». 2015. 20 июля. URL: http://ru.rfi.fr/frantsiya/20150720-frantsiya-primet-novyi-zakon-dlya-inostrantsev

${ }^{33}$ France - New Law on the Rights of Foreigners // Visalaw International. 2016. 21 of March. URL: http://www.visalawint.com/latest-news/france-new-law-on-the-rights-of-foreigners-8-march-2016

${ }^{34}$ Стрельцова Я. Современная миграционная политика Франции // Мировая экономика и международные отношения. 2020. Т. 64. № 8. С. 120-127.

${ }^{35}$ Ibid. C. 122.

${ }^{36}$ Мігранти прориваються до Європи. Франція допоможе Греції та Болгарії стримувати іх // Суспільне. Новини. 2020. 2 березня. URL: https://suspilne.media/17142-migranti-prorivautsa-do-evropi-francia-dopomozegrecii-ta-bolgarii-strimuvati-ih/
} 
62,7 млн. євро. Окрім того, Франція планує збільшити кількість патрулів на кордонах 3 Італією та Іспанією, а Лондон, у свою чергу, зробити острів менш привабливим для шукачів притулку, а також застосовувати санкції щодо нелегальної міграції та тих, хто робить їі можливою ${ }^{37}$.

Проте, вже наприкінці серпня 2021 р. за повідомленнями 3МI, міністр внутрішніх справ Британії Пріті Пател заявила, що обіцяні кошти Франції, будуть витрачені на вирішення проблеми великої кількості мігрантів (лише 21 серпня 2021 р. затримали 828

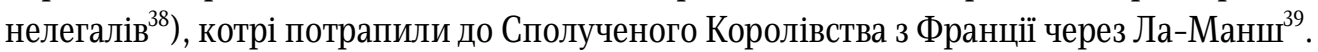

10 жовтня 2021 р. Е. Макрон закликав Велику Британію та EC до якнайшвидшого початку переговорів. Глава МЗС Франції Жеральд Дерманен заявив, що розробка міграційної угоди між Великою Британією та Європейським Союзом є надзвичайно важливим моментом. Оскільки наявність цієї угоди дасть можливість, об'єднавши зусилля, продуктивніше протистояти нелегальним міграційним потокам, які на 50\% зросли порівняно 32020 р. (15,4 тис. осіб перетнули Ла-Манш упродовж січня-серпня 2021 р. $)^{40}$.

Серйозність даного питання полягає й у тому, що докладаючи максимальних зусиль у контролі традиційних шляхів потрапляння нелегальних мігрантів 3 країн Близького Сходу, Африки та Азії, Франція, як і більшість європейських держав, на початку 2021 р. зіштовхується з потоками мігрантів через Білорусію, велика кількість яких наразі зосередилася біля кордонів Польщі, Литви та Латвії. Ще наприкінці травня 2021 p. О. Лукашенко у відповідь на санкції ЄС заявив, що перестане стримувати рух мігрантів через свою країну до Литви ${ }^{41}$. У результаті, упродовж липня-жовтня 2021 р. ситуація досягла свого апогею.

Отже, як бачимо, ситуація з нелегальною міграцією як у самій Франції, так й в інших країнах Європи є досить складною. I не може бути вирішеною в «один клік». Якщо першочергово збільшення мігрантів на території тієї чи іншої країни ЄC в основному впливало на економічну складову, то наразі це дійсно є серйозний дестабілізуючий фактор безпеки не лише Франції, Німеччини, Англії, а всього регіону. Тому, перед а́кторами сучасної арени міжнародних відносин стоїть важливе завдання докласти максимальних зусиль для прийняття стратегії подолання цієї небезпеки.

На нашу думку, можна виділити такі ключові напрями боротьби 3 масовими потоками біженців. По-перше, усі члени-держави ЄC повинні об'єднати свої зусилля та підписати нову дієву угоду щодо нелегальної міграції і подолання її наслідків, прописавши загальні правила прийому легальних мігрантів і механізм депортації нелегальних. По-

\footnotetext{
${ }^{37}$ Франція та Британія посилюють контроль за незаконною міграцією // Радіо Свобода. Новини міжнародні. 2021. 21 липня. URL: https://www.radiosvoboda.org/a/news-uk-france-migrants/31369581.html

${ }^{38}$ Біля берегів Британії перехопили рекордну кількість нелегалів // Укрінформ. 2021. 25 серпня. URL: https://www.ukrinform.ua/rubric-world/3303530-bila-beregiv-britanii-perehopili-rekordnu-kilkist-nelegaliv.html ${ }^{39}$ Франція хоче чимскоріше провести переговори з Британією стосовно біженців // Укрінформ. 2021. 10 жовтня. URL: https://www.ukrinform.ua/rubric-world/3330368-francia-hoce-cimskorise-provesti-peregovoriz-britanieu-stosovno-problem-bizenciv.html

${ }^{40}$ Ibidem.

${ }^{41}$ Сiтнікова I. Ще одна країна звинуватила Білорусь в організації каналу незаконних мігрантів. Париж натякає на родичів Лукашенка // Громадське. URL: https://hromadske.ua/posts/u-dnipri-vikrili-likarya-yakijshodnya-robiv-do-30-fejkovih-covid-sertifikativ-dokumenti-anulyuyut
} 
друге, усі держави-члени повинні посилити контроль на кордонах, задіявши сучасне технологічне оснащення. Створити єдину автоматизовану систему інформаційного забезпечення правоохоронних органів у боротьбі з нелегальною міграцією. Також обєднати зусилля у боротьбі з посередниками нелегальної міграції, створивши, можливо, єдину базу даних. Окрім цього, європейським країнам варто проявляти більш активну позицію у вирішені конфліктних ситуацій у країнах, звідки тікають люди, в пошуку кращого життя та власного порятунку від зброї чи голоду. Звісно, це можуть бути абсолютно інші варіанти, але у будь-якому випадку вони потребуватимуть об'єднаної позиції усіх держав-членів ЄС, бо «один у полі не воїн».

Liudmyla Vovchuk, Inna Avdiushkina

\section{French Policy in the Field of Settlement of the Illegal Migration' Problem}

Abstract: This article focuses on France's policy in the field of illegal migration, which has played an important role in the political transformation of the country and the EU as a whole. The global financial and economic crisis of 2009, conflict in third world countries made serious «adjustments» to the process of illegal migration to European countries, which in the following years grew into a difficult to control process, which is now a serious destabilizing factor in the region. Over the last fifteen years, the EU's migration policy has changed significantly and taken on a new meaning. However, as the example of France's fight against illegal migration shows, it is extremely difficult for one to do so, as the problem is no longer national but international.

One of the main lobbyists for the implementation of the updated migration policy package is Nicolas Sarkozy, who during his political career passed a number of rather strict and restrictive laws and amendments to regulations, the main purpose of which was to improve the general social climate. To regulate migration processes, the French government has created a multi-level system of government agencies and bodies.

The final stage of reforming French migration policy was the adoption on March 8, 2016 of the Law on Foreigners, which contained provisions on the reception and integration of immigrants, a new procedure for issuing residence permits, and provisions on illegal migrants in the country.

In 2017, France focused on supporting the actions of EU states to protect the external borders, which included strengthening the police corps and increasing the number of border police in the framework of building a single pan-European border control system; establishment of checkpoints in the countries of origin of migrants in order to limit the number of refugees before arriving in the EU; stepping up the fight against illegal immigration in the EU and its organizers. During 2019-2021, the French government took a number of other important steps to combat illegal migration in the country and the region.

Keywords: illegal migration, migration policy, France, EU 